\title{
Questionnaire-Driven: Konfigurasi Sistem Informasi Pembayaran SPP Sekolah
}

\author{
Muhammad Syahrul Faizin', Muhammad Fahmi Abidin², Baso Abrar Usman ${ }^{3}$, M. Ainul Yaqin ${ }^{4}$ \\ Jurusan Teknik Informatika, UIN Maulana Malik Ibrahim Malang \\ Jl. Gajayana No.50, Dinoyo, Kec. Lowokwaru, Kota Malang, Jawa Timur 65144 \\ 1muhammadsyahrulfaizin23@gmail.com,2fahmiabidin13@gmail.com, \\ 33basoabrarusman@gmail.com, 4yaqinov@ti.uin-malang.ac.id
}

\begin{abstract}
Schools must have a process model which describes the structured flow that is appropriate in every action to be taken in activities at the school, especially in payment process SPP. Even though it has entered the millennial era, there are still many schools that use the SPP payment process model using the manual method, because they have to adjust to the environment. To get the appropriate process model, an information system configuration is needed in which an information system can create an appropriate process model. To configure an information system, it must obtain configuration data from the environment obtained through Questionnaire-Driven. From the data obtained from Questionnaire-Driven, an information system configuration process is carried out to determine the payment process model of the school SPP payment system.
\end{abstract}

Keywords: Questionnaire Driven, Information System Configuration, Process Model, SPP School Payment

Abstrak
Sekolah harus mempunyai model proses yang dimana menggambarkan aliran terstruktur yang sesuai dalam setiap tindakan yang akan diambil dalam kegiatan di sekolah terlebih dalam hal proses pembayaran SPP. Meskipun sudah masuk pada zaman milenial, namun masih banyak sekolah melakukan model proses pembayaran SPP menggunakan cara manual, karena harus menyesuaikan dengan keadaan lingkungan sekitar. Untuk mendapatkan model proses yang sesuai, diperlukanlah konfigurasi sistem informasi yang dapat membuat system informasi yang berisi sebuah model proses yang sesuai. Untuk melakukan konfigurasi sistem informasi, harus mendapatkan data-data konfigurasi dari lingkungan yang didapatkan melalui Questionnaire-Driven. Dari data yang telah didapatkan dari Questionnaire-Driven, maka dilakukanlah proses konfigurasi sistem informasi untuk menentukan model proses sistem pembayaran SPP sekolah.

Kata Kunci: Questionnaire-Driven, Konfigurasi Sistem Informasi, Model Proses, Pembaran SPP Sekolah

\section{PENDAHULUAN}

Pendidikan merupakan salah satu bagian penting dari proses pembangunan nasional yang menentukan masa depan negara. Pendidikan merupakan investasi negara pada sumber daya manusia dengan meningkatkan kemampuan dan keterampilan sehingga peradaban bangsa mempunyai harkat dan martabat yang lebih baik dan maju. Karena harkat dan martabat negara terletak pada peradaban yang dibangun oleh sumber daya manusia yang dimilikinya. Dalam mengelola sebuah instansi pendidikan yang terpikir hanyalah bagaimana cara untuk memberi pelayanan yang efektif dan efisien dengan sumber daya yang ada? sehingga kegiatan belajar-mengajar menjadi nyaman dan menyenangkan. Sebagian besar instansi pendidikan menggunakan cara manual dalam mengelola dan memberi pelayanan karena terbatasnya sumber daya yang menyebabkan pengelolaan dan pemberian layanan dirasa kurang efektif dan efisien. Satu contoh pembayaran 
uang bulanan SPP yang hanya bisa melayani dengan uang cash saja sehingga didapat suatu kerepotan wali murid yang tidak mempunyai banyak waktu luang untuk datang dan mengantri di loket pembayaran SPP [1]. Sehingga banyak yang menunda pembayaran bulanan SPP sampai wali murid benar-benar mendapati waktu luang yang pas untuk datang dan mengantri di loket pembayaran SPP.

Seiring berkembangnya teknologi informasi yang sangat pesat dan merambah ke berbagai aspek kehidupan tanpa terkecuali dalam pendidikan. Salah satu contoh dampak perkembangan teknologi informasi pada pendidikan yaitu wali murid dapat membayar SPP sekolah melalui e-banking atau dengan memanfaatkan uang virtual yang berlaku [2]. Dalam hal ini teknologi informasi berperan untuk mengelola dan memberikan pelayanan. Oleh karena itu untuk memberikan pelayanan yang efektif dan efisiensi dalam tulisan ini kami ingin menawarkan sebuah konfigurasi informasi dalam menyusun pelayanan yang efektif dan efisien, yakni sebuah sistem informasi sekolah yang didalamnya terdapat model proses yang memuat berbagai fitur yang dapat menyesuaikan kebutuhan sekolah dalam mengelola dan memberikan pelayanan yang efektif dan efisien dalam hal finansial [3].

\section{METODOLOGI PENELITIAN}

Questionnaire-driven merupakan metode identifikasi dan analisis dengan alat utamanya adalah sebuah kuesioner yang terdiri dari beberapa pertanyaan-pertanyaan yang mewakili dari tujuan identifikasi atau analisis yang akan dicapainya [4]. Dalam penelitian ini, kami merancang kuesioner dalam 3 bagian group pertanyaan yang setiap bagian memiliki tujuan untuk mengidentifikasi fakta-fakta untuk menkonfigurasi pembayaran bulanan SPP sekolah. Tujuan, tipe jawaban dan format jawaban disediakan pada Tabel 1.

Tabel 1. Desain Questionnaire-Driven

\begin{tabular}{|l|l|l|}
\hline \multicolumn{1}{|c|}{ Tujuan } & \multicolumn{1}{|c|}{ Tipe Jawaban } & \multicolumn{1}{c|}{ Format Jawaban } \\
\hline $\begin{array}{l}\text { Identifikasi metode } \\
\text { transaksi pembayaran } \\
\text { bulanan SPP }\end{array}$ & $\begin{array}{l}\text { 3 pertanyaan yang } \\
\text { menunjukan perbedaan } \\
\text { metode transaksi } \\
\text { pembayaran }\end{array}$ & $\begin{array}{l}\text { Multiple Choice yaitu memilih } \\
\text { diantara 2 jawaban yang } \\
\text { merujuk ke pertanyaan } \\
\text { selanjutnya. }\end{array}$ \\
\hline $\begin{array}{l}\text { Identifikasi model } \\
\text { pencatatan pembayaran }\end{array}$ & $\begin{array}{l}\text { 2 pertanyaan mengenai } \\
\text { SpP } \\
\text { pembayaran SPP }\end{array}$ & $\begin{array}{l}\text { Multiple Choice yaitu memilih } \\
\text { diantara 2 jawaban yang } \\
\text { berkesinambungan dengan } \\
\text { pertanyaan-pertanyaan } \\
\text { sebelum dan setelahnya. }\end{array}$ \\
\hline $\begin{array}{l}\text { penyimpanan data } \\
\text { pencatatan pembayaran } \\
\text { SPP }\end{array}$ & $\begin{array}{l}\text { 1 pertanyaan penyimpanan } \\
\text { data yang berisi catatan } \\
\text { pembayaran SPP seperti } \\
\text { tanggungan dan pelunasan } \\
\text { SPP bulanan. }\end{array}$ & $\begin{array}{l}\text { Multiple Choice yaitu memilih } \\
\text { diantara 2 jawaban yang } \\
\text { menghubungkan dengan } \\
\text { pertanyaan-pertanyaan } \\
\text { sebelum. }\end{array}$ \\
\hline
\end{tabular}


Dari rumusan Tabel 1 akan didapati berbagai macam bentuk dan model jawaban. setiap soal kuesioner yang akan memberikan informasi dalam memodelkan sebuah konfigurasi sistem pembayaran bulanan SPP sekolah yang sesuai dengan kebutuhan sekolah.

\section{HASIL DAN PEMBAHASAN}

Untuk membuat suatu konfigurasi, kami mencoba dengan cara menyusun serangkaian fakta-fakta dalam sistem pembayaran bulanan SPP sekolah [5]. Melalui kuesioner interkatif yang akan memandu konfigurasi hanya dengan mengajukan beberapa pertanyaan yang saling keterkaitan untuk merujuk kepada fakta-fakta yang telah disusun [6]. Fakta mempunyai nilai masing-masing dapat berupa wajib jika yang dijawab menunjukan suatu yang wajib ada dalam menentukan fakta lain yang berkesinambungan dan dapat bernilai opsional jika jawaban pertanyaan merujuk pada fakta yang bersifat opsional [7].

Fakta-fakta yang telah disusun kemudian dikelompokan dalam pertanyaan yang sesuai dengan nilai fakta tersebut sehingga dari beberapa pertanyaan dapat menunjukan dari nilai sebuah fakta dengan begitu dapat diset sekaligus dengan menjawab pertanyaan-pertanyaan yang terkait. Pengaturan fakta merupakan kombinasi dari semua nilai fakta yang dimiliki dan ditetapkan baik secara eksplisit dengan menjawab pertanyaan atau dengan menggunakan standarnya. Gambar 1. menggambarkan struktur kemungkinan jawaban untuk mewakili fakta-fakta yang telah ditetapkan.

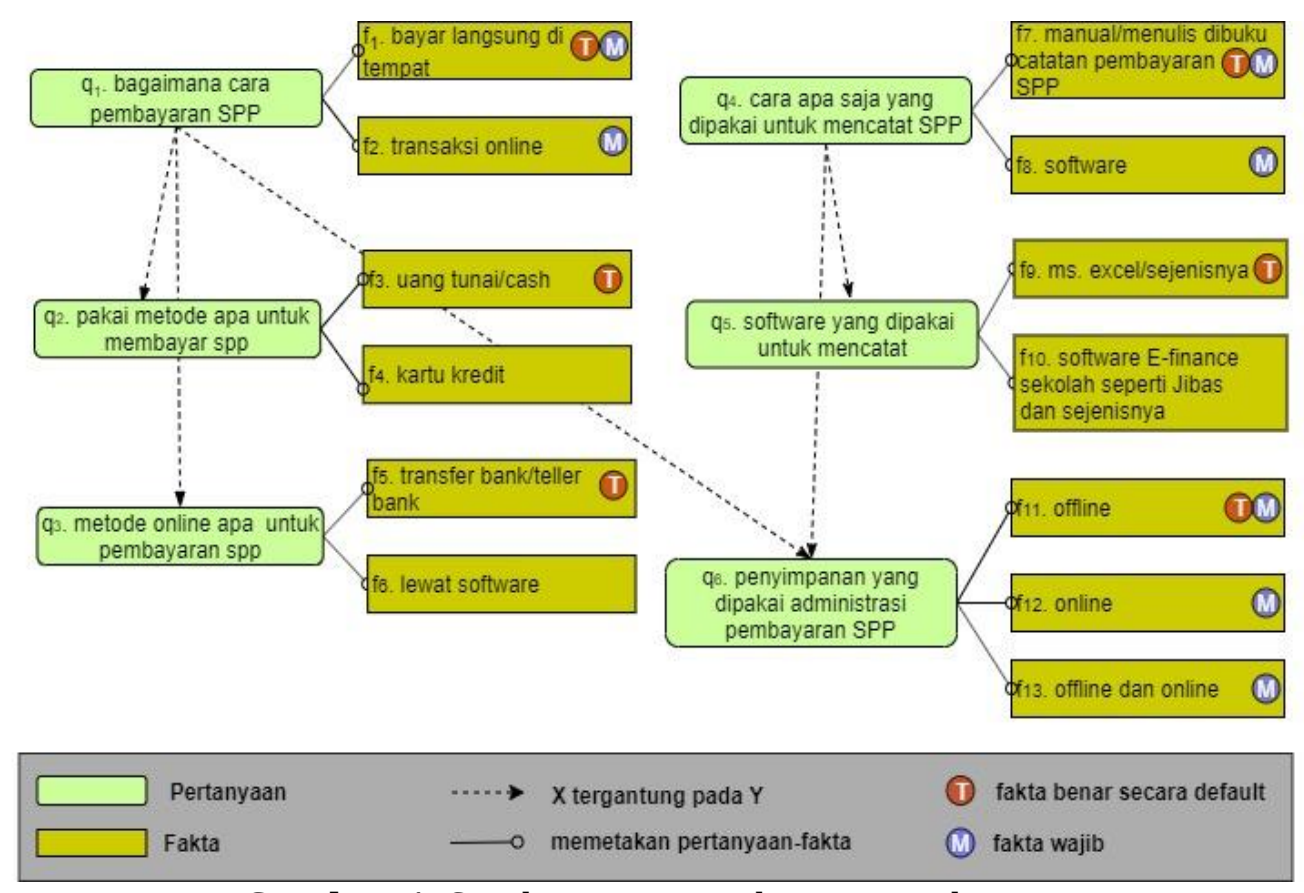

Gambar 1. Struktur Kemungkinan Jawaban 
Jurnal Riset Sistem Informasi Dan Teknik Informatika (JURASIK) Volume 5 Nomor 1 Februari, pp 97-101 ISSN: 2527-5771/EISSN: 2549-7839

http://tunasbangsa.ac.id/ejurnal/index.php/jurasik

Dari gambar 1. Semua pertanyaan dan fakta diberi id dan deskripsi. Misalnya, fakta f1 hingga f2 merujuk pada kisaran cara pembayaran SPP sehingga dikelompokan dalam 1 pertanyaan dengan fakta yang bersifat wajib karena menjadi dasar dalam memilih metode pembayaran yang akan digunakan. Nilai default ditetapkan untuk mencerminkan pilihan khas yang dibuat cara pembayaran dengan datang di tempat dengan metode pembayaran secara tunai dan akan dicatat langsung secara manual dalam buku catatan pembayaran SPP pada umumnya. Oleh karena itu f1 di q1 memiliki nilai default sama dengan true begitu juga f3 dan f4 di q2 yang berhubungan dengan pertanyaan metode pembayaran SPP seperti hanya fakta lainya. Berlaku juga untuk pertanyaan lain yang memungkinkan untuk memilih metode pencatatan $(q 3, q 4)$ dan penyimpanan data pembayaran SPP (q5).

Depedensi menjadi penentu urutan parsial dalam mengajukan pertanyaan kepada pengguna. Ketergantungan biasa. Garis panah putus-putus menunjukan ketergantungan biasa yang digunakan untuk menunjukan pertanyaan yang kemungkinan memiliki ketergantungan pada pertanyaan lain. Depedensi juga dapat didefinisikan dengan fakta yang memiliki aturan sama. Dari pertanyaan tersebut akan menghasilkan banyak variasi jawaban yang kemudian variasi jawaban tersebut akan diproses melalui proses konfigurasi sistem informasi. Hasil proses konfigurasi sistem informasi tersebut akan menghasilkan berbagai model proses yang dimana model proses tersebut akan mepresentasikan sistem pembayaran SPP yang dipakai oleh sekolah.

\section{SIMPULAN}

Pada hasil penelitian yang telah dilakukan, bahwa metode Questionnaire-Driven yang dimana variasi jawaban pada Questionnaire-Driven dapat digunakan untuk melakukan proses konfigurasi sistem informasi. Model proses yang didapatkan dari konfigurasi sistem informasi dapat dipakai oleh sekolah dimana model proses tersebut akan mepresentasikan sistem pembayaran SPP. Namun konfigurasi masih belum optimal karena alur pembayaran SPP pada pertanyaan Questionnaire-Driven adalah alur pembayaran SPP secara umum, jadi tidak semua sekolah bisa memakai model proses dari penelitian ini karena ditiap-tiap sekolah mempunyai alur pembayaran SPP yang berbeda-beda.

\section{DAFTAR PUSTAKA}

[1] Pamungkas, R. "Perancangan Sistem Informasi Pembayaran Administrasi SMK Negeri 1 Jiwan”. Jurnal INTENSIF, Vol.1 No.2 Agustus 2017.

[2] Juniadi, J. "Konsep Otomatisasi Sistem Pembayaran SPP Online Untuk Mengurangi Tingkat Keterlambatan". Konferensi Nasional Sistem \& Informatika 2015.

[3] Lee, D.Y., Won, S.K., Han, C.H., Cho, M.Y., and Lee, J.B. "Application of Configuration Management for Engineering Information Management in Pipeline Projects". 34th International Symposium on Automation and Robotics in Construction, 2017.

[4] Estublier, J. "Software Configuration Management : A Roadmap". Dassault Systèmes / LSR, Grenoble University Bat C, BP 5338041 Grenoble 9 France, 2000.

[5] Aguiar, J.G., Kinchin, I.M., Heron M., Correi, P.R.M. "Comparing Interview-Driven and Questionnaire - Driven Concept Mapping Processes: A Focus On The Research-Teaching 
Jurnal Riset Sistem Informasi Dan Teknik Informatika (JURASIK) Volume 5 Nomor 1 Februari, pp 97-101 ISSN: 2527-5771/EISSN: 2549-7839

http://tunasbangsa.ac.id/ejurnal/index.php/jurasik

Nexus In Higher Education". Eighth International Conference on Concept Mapping, 2018.

[6] La Rosa, M., Lux, J., Seidel, S., Dumas, M., \& Ter Hofstede, A. H. M. "Questionnaire-driven configuration of reference process models". In Lecture Notes in Computer Science (including subseries Lecture Notes in Artificial Intelligence and Lecture Notes in Bioinformatics), Vol. 4495 LNCS, pp. 424-438 2007.

[7] Kang M., and Jung Y. "Framework \& Functions of Configuration Management (CM) in Nuclear Power Plants (NPP)", Korean Journal of Construction Engineering and Management, KICEM, 16(3): 101- 112, 2015 